\title{
Phospholipase A2 Isoforms in Benzo (a) Pyrene- Induced Molecular Changes in Colon Cancer Cells: A Plausible Therapeutic Target
}

Sanjeev K Sharma ( $\sim$ indianbhardwaj@gmail.com )

Post Graduate Institute of Medical Education and Research

\section{Subodh K Yadav}

PGIMER

\section{Ujjawal Sharma}

Post Graduate Institute of Medical Education and Research

Pramod Avti

Post Graduate Institute of Medical Education and Research

\section{SatyatiVati Rana}

Post Graduate Institute of Medical Education and Research

Krishan Lal Khanduja

Post Graduate Institute of Medical Education and Research

\section{Research}

Keywords: Colorectal cancer, Cigarette smoke condensate, Phospholipases A2, Colon cell lines, Reactive oxygen species, siRNA

Posted Date: April 30th, 2020

DOl: https://doi.org/10.21203/rs.3.rs-25037/v1

License: (c) (1) This work is licensed under a Creative Commons Attribution 4.0 International License. Read Full License 


\section{Abstract}

Background: Colorectal cancer (CRC) is the third most common cancer prevalent in men, and the second in women worldwide. The exact cause and pathogenesis of this disease remains unknown. In every cell multiple phospholipase $A_{2}\left(P L A_{2}\right)$ exists, but their contribution to the cell function has yet not been determined. The increased activity of these isoforms may be important in the generation of inflammatory mediators which finally are involved in the initiation of carcinogenesis. This study has explored the pathways involved in the differential response of HCT-15 and HT-29 colon cell lines during benzo(a)pyrene $[\mathrm{B}(\mathrm{a}) \mathrm{P}]$-induced molecular changes.

Methods: HT-29 and HCT-15 cells were used for the present study. Benzo(a)pyrene [B(a)P]-induced molecular changes were evaluated through cell viability using MTT assay, reactive oxygen species (ROS) measurement using 2,7 dichloro-dihydro-fluorescin diacetate (DCFH-DA), The gene expressions of PLA2 isoforms were estimated by RT- PCR. Further, knockdown of PLA ${ }_{2}$ isoform in transfected cells was done with siRNA.

Results: The cell viability decreased significantly after exposure with $\mathrm{B}(\mathrm{a}) \mathrm{P}$ in both cell lines. Reactive oxygen species (ROS) production after exposure with $\mathrm{B}(\mathrm{a}) \mathrm{P}$ was significantly induced in both types of colon cell lines. The gene expressions of PLA2 isoforms were also estimated. Three PLA $\mathrm{A}_{2}$ isoforms such as IB and, IID, IVA were induced after exposure with B(a)P respectively in HT -29 and HCT-15 cell lines. Further, a significant knockdown of $\mathrm{PLA}_{2}$ isoform in transfected cells with siRNA, and $\mathrm{B}(\mathrm{a}) \mathrm{P}$ exposure was observed in HCT-15 and HT-29 cells. There was a significant induction of ROS in IVA transfected HCT15 cells exposure with $B(a) P$.

Conclusion: It is concluded that each cell line behaved differently, specific $\mathrm{PLA}_{2}$ siRNA are involved in controlling the cascades related ROS, depending upon the origin of the cells. Secretary phospholipase $\mathrm{A}_{2}$ $\left(\mathrm{sPLA}_{2}\right)$ inhibitors are likely to have a therapeutic potential in colon pathologies.

\section{Introduction}

Colorectal cancer (CRC) is the third most common cancer in men and the second in women worldwide [1]. The incidence of CRC has been reported to increase 2-4 times in the past few decades in many countries of the Asia-Pacific region. Presently the most common treatment option is surgery, and that also depends on various factors like the site of the cancer and the presence and extent of metastasis. The risk of colorectal cancer begins with the formation of abnormal polyp growth that later grows to cancer. The major causes include the over-eating, alcohol consumption and smoking. Studies also suggest that a proper life-style maintenance including the controlled diet could reduce the abnormal poly formation and further cancer. Ursolic acid is a phytochemical present in most plants and has the ability to reduce the cell proliferation of breast and colon cancer cells through various pathways [2]. The Benzo(a)pyrene [B(a)P], a known carcinogen, presents in diet and environment such as cigarette smoke (CS), grilled meats and byproducts of industrial incineration [3]. The oxidative stress caused by the constituents of CS such as 
$\mathrm{B}(\mathrm{a}) \mathrm{P}$ in normal as well as in the mutated cells may lead to the remodeling of membrane lipids through upregulation of various signaling events such as activation of lipid specific enzymes especially phospholipases. Almost in every cell type, multiple isoforms of phospholipase $A_{2}\left(P L A_{2}\right)$ but their contribution to the cell functions has not yet been clearly determined.

Phospholipase $A_{2}$ superfamily is composed of many lipolytic enzymes whose common feature is to hydrolyze the fatty acid present in the sn-2 position of glycerophospholipids. It is reported that PLA 2 can act synergistically with reactive oxygen species (ROS) to cause cellular injury due to enhanced susceptibility of peroxidized membrane to the action of $\mathrm{PLA}_{2}$. Phospholipases type $\mathrm{A}_{2}$ is involved in the generation of a wide range of biomediators, including lysophospholipids, arachidonic acid, and metabolites of arachidonic acid that can enhance tumor cell growth, invasion, and metastasis [4]. However, it is not known whether PLA $\mathrm{A}_{2}$ isoforms are expressed in human colon cancer and whether PLA 2 isoforms influence the malignant potential of colon cancer cells. Besides that, $\mathrm{PLA}_{2}$ isoenzymes may behave differentially to cigarette smoke condensate (CSC) and $\mathrm{B}(\mathrm{a}) \mathrm{P}$ (a major carcinogen of cigarette smoke) in vitro.

This study aims to explore the pathways involved in the differential response of HCT-15 and HT-29 colon cell lines during $[\mathrm{B}(\mathrm{a}) \mathrm{P}]$-induced molecular changes.

\section{Methods}

\section{Cell lines:}

Colon adenocarcinoma cancer cell lines (HCT-15 and HT-29) were procured from National Centre for Cell Science, Pune, India.

\section{[b(a)p] Preparation:}

$\mathrm{B}(\mathrm{a}) \mathrm{P}$ were procured from sigma USA and dissolved in DMSO, the working concentration $(0.025 \%)$ was prepared in a sterile medium.

\section{Cell Culture:}

HCT-15 and HT-29 were maintained in continuous culture at $37{ }^{\circ} \mathrm{C}$ and $5 \% \mathrm{CO}_{2}$ in RPMI- 1640 and DMEM medium supplemented with $10 \%$ fetal bovine serum (FBS), $2 \mathrm{mM} \mathrm{L-glutamine,} 100$ units/ml penicillin, $100 \mu \mathrm{g} / \mathrm{ml}$ streptomycin and $0.5 \mu \mathrm{g} / \mathrm{ml}$ fungizone respectively.

\section{Cell Viability Assay:}


Effect of $B(a) P$ on cell viability was evaluated by the 3-(4, 5- dimethylthiazol-2-yl)-diphenyltetrazolium bromide (MTT) dye uptake method described previously [5]. Briefly, $2 \times 10^{3}$ cells were seeded in 96 - well plates, and treated with varying concentrations of B(a)P for $24 \mathrm{hr}, 48 \mathrm{hr}$, and $72 \mathrm{hr}$. After the desired incubation time, $20 \mu \mathrm{l}$ of MTT solution $(2.5 \mathrm{mg} / \mathrm{ml})$ was added to each well. After $4 \mathrm{hr}$, resultant formazan crystals were dissolved in $40 \mu \mathrm{l}$ of lysis buffer (20\% SDS dissolved in $50 \%$ each of DMF and $\mathrm{ddH}_{2} \mathrm{O}$ ). The developed colour was read at $570 \mathrm{~nm}$ on ELISA reader.

\section{Ros And Superoxide Radicals (sor):}

Levels of intracellular ROS, mitochondrial ROS and SOR were measured by the shift in fluorescent intensity resulting from oxidation of DCFH-DA (for ROS), DHR123 (for Mitochondrial ROS) and DHE (for Superoxide radical) fluorescence dye [6]. Briefly, $0.5 \times 10^{5}$ cells/well were seeded into 12-well plates and allowed to grow overnight in complete media. After $24 \mathrm{hr}$ of incubation, the medium was replaced with a fresh medium and the cells were treated with varying concentrations of $B(a) P$ for a specific time interval. Cells were incubated with $5 \mu \mathrm{M}$ DCFH-DA, $10 \mu \mathrm{M}$ DHR123 or $10 \mu \mathrm{M}$ DHE fluorescence dye for $30 \mathrm{~min}$. Cells were challenged with B(a)P for $24 \mathrm{hr}$ and $48 \mathrm{hr}$. Thereafter, cells were washed, harvested and resuspended in chilled phosphate buffer saline (PBS). Finally, cells were subjected to fluorescenceactivated cell sorting (FACS; Beckton Dickinson FACSCan). Levels of ROS and SOR were represented in terms of mean fluorescent intensity (MFI).

\section{Rna Extraction And Cdna Synthesis:}

Total RNA was isolated by using Trizol reagent according to the manufacturer's instructions. Briefly, $1 \mathrm{ml}$ Trizol reagent was added to the cells followed by chloroform. The mixture was incubated at room temperature for $15 \mathrm{~min}$ and centrifuged at $12000 \mathrm{xg}$ for $15 \mathrm{~min}$ at $4^{\circ} \mathrm{C}$ resulting in the separation of an upper aqueous phase and lower organic phase. The upper aqueous phase was carefully transferred to a fresh eppendorf tube. After adding and shaking with isopropanol mixture was incubated for $10 \mathrm{~min}$ and then centrifuged at $12000 \mathrm{xg}$ for $10 \mathrm{~min}$. The pellet thus obtained was washed with $75 \%$ ethanol followed by centrifugation for $5 \mathrm{~min}$ at 7,500 $\mathrm{xg}$. The RNA pellet was air-dried and dissolved in an appropriate volume of DEPC water and stored at $-80^{\circ} \mathrm{C}$. Spectrophotometric measurement of RNA was done to quantify its purity. Further, one microgram RNA was used for cDNA synthesis. The cDNA synthesis was carried out from the purified and intact total RNA by using the Revert AidTM first strand cDNA synthesis kit (Fementas) according to the manufacturer's instructions.

\section{Reverse Transcription-polymerase Chain Reaction (rt-pcr):}

Effect of $\mathrm{B}(\mathrm{a}) \mathrm{P}$ on mRNA expression of PLA $\mathrm{A}_{2}$ isoforms was conducted through RT-PCR for the analysis of mRNA levels of PLA 2 groups (IB, IID, III, IVA, IVB, IVC, VI, X, acid iPLA $A_{2}$, iPLA $)_{2}$ ). In RT-PCR reactions (25 $\mu$ l) $100 \mathrm{ng}$ cDNA was used as template DNA. The primer sequences were designed from the mRNA sequence 
of genes available in the Genebank or from previously published literature. The details of primer sequences and RT-PCR conditions used for the study are given in Table 1. The expression levels of different genes were calculated by relative quantification using b-actin transcript levels for normalization. The fold change in mRNA expressions was calculated by the comparative $\Delta \Delta \mathrm{Ct}$ method [7].

Table 1

Primer Sequences of various genes

\begin{tabular}{|c|c|c|c|}
\hline S.No. & Name & Primer Sequence & Product Size (bp) \\
\hline \multirow[t]{2}{*}{1} & $P L A_{2}-I B$ & [s], 5'- CTCAGGCACCCCCGTGGATGA - 3' & 207 \\
\hline & & [a], 5'- GCGTTGCGGTCGCAGTTGCA - 3' & \\
\hline \multirow[t]{2}{*}{2} & $\mathrm{PLA}_{2}-\mathrm{IID}$ & [s], 5'- СACCTGCTGGCCCCCTTGTC-3' & 244 \\
\hline & & [a], 5'- CAGGCATGGCCTCCACCTGC - 3' & \\
\hline \multirow[t]{2}{*}{3} & $\mathrm{PLA}_{2}-\mathrm{III}$ & [s], 5'-ACAACTCTTCTATGCCTGG-3' & 256 \\
\hline & & [a], 5'-TGTGACATCCCTAACTTCC-3' & \\
\hline \multirow[t]{2}{*}{4} & PLA - IVA & [s], 5'-GTTGCTGGTCTTTCTGGCTC-3' & 313 \\
\hline & & [a], 5'-GGTAAAGGGCATTGTGCAGT-3' & \\
\hline \multirow[t]{2}{*}{5} & $\mathrm{PLA}_{2}-\mathrm{IVB}$ & [s], 5'- GCTGCAAGGGAGCTCTGCGT - 3' & 286 \\
\hline & & [a], 5'- CCAGCACGAAGCTCAGGGGC - 3' & \\
\hline \multirow[t]{2}{*}{6} & $\mathrm{PLA}_{2}-\mathrm{IVC}$ & [s], 5'-CGATTTACCCGAGGAGTGG-3' & 329 \\
\hline & & [a], 5'-GCTTCCGAAGTGGGTTATGG-3' & \\
\hline \multirow[t]{2}{*}{7} & $\mathrm{PLA}_{2}-\mathrm{VI}$ & [s], 5'-TGCGCAACCGCTTCGACTGT-3' & 214 \\
\hline & & [a], 5'-AGTTGTCTGCCGATTTTGGAGGC-3' & \\
\hline \multirow[t]{2}{*}{8} & $\mathrm{PLA}_{2}-\mathrm{X}$ & [s], 5'- TCCCTTATTCCGAGGAGACTTCCCT - 3' & 395 \\
\hline & & [a], 5'- CCACGCCGGTGCACACGTAA - 3' & \\
\hline \multirow[t]{2}{*}{9} & Acid-iPLA 2 & [s], 5'- AGGTCTGCTTCTCGGGGACGTG - 3' & 241 \\
\hline & & [a], 5'- GCTCCAGGCAAGATGGTCCTCA - 3' & \\
\hline \multirow[t]{2}{*}{10} & iPLA -2 & [s], 5'- GGACCCGGGCATTAGTTCAGGCA - 3' & 286 \\
\hline & & [a], 5'- GCAACCACGCCCCTTGTTCCT - 3' & \\
\hline
\end{tabular}

\section{Pla Gene Silencing:}

$\mathrm{PLA}_{2}$ siRNA (IB, IID and IVA from Sigma Aldrich, USA) and scrambled siRNA were transfected into HCT-15 cells using transfection lipofectamine ${ }^{\mathrm{Tm}} 2000$ reagent as described previously [8]. The sequences of all 
siRNAs used in this study are provided in Table 2. Briefly, in HT-29 (IB) and HCT-15 (IID and IVA) cells the $\mathrm{PLA}_{2}$ gene was silenced by using specific siRNA against the group IB, IID and IVA PLA 2 gene. The cells (1 $\times 10^{5}$ per well) were seeded in $2 \mathrm{ml}$ antibiotic-free medium supplemented with $10 \%$ FBS in a six-well culture plate. After $60-80 \%$ confluency the cells were siRNA (IB, IID and IVA from Sigma Aldrich, USA) and scrambled siRNA were transfected into HCT-15 cells using transfection lipofectamine ${ }^{\text {TM }} 2000$ reagent. Briefly, in HT-29 (IB) and HCT-15 (IID and IVA) cells the PLA ${ }_{2}$ gene was silenced by using specific siRNA against the group IB, IID and IVA PLA $A_{2}$ gene. The cells $\left(1 \times 10^{5}\right.$ per well) were seeded in $2 \mathrm{ml}$ antibiotic free medium supplemented with $10 \%$ FBS in a six well culture plate. After $60-80 \%$ confluency the cells were transfected with transfection reagents for $6-8 \mathrm{hr}$ at $37^{\circ} \mathrm{C}$ in a $\mathrm{CO}_{2}$ incubator following the recommended protocol provided with siRNA oligos. Before transfection, the medium was replaced with fresh medium without antibiotics. After transfection, additional media was added with $20 \%$ FBS so that the final concentration of FBS becomes $10 \%$ in the final mixture followed by the treatment with a specific concentration of $\mathrm{B}(\mathrm{a}) \mathrm{P}$ for $48 \mathrm{hr}$. After completion of the incubation time, total RNA was isolated as mentioned above transfected with transfection reagents for $6-8 \mathrm{hr}$ at $37^{\circ} \mathrm{C}$ in a $\mathrm{CO}_{2}$ incubator following the recommended protocol provided with siRNA oligos. Before transfection, the medium was replaced with fresh medium without antibiotics. After transfection, additional media was added with $20 \%$ FBS so that, the final concentration of FBS becomes $10 \%$ in the final mixture followed by the treatment with a specific concentration of $\mathrm{B}(\mathrm{a}) \mathrm{P}$ for $48 \mathrm{hr}$. After completion of the incubation time, total RNA was isolated as mentioned above. Similarly, one microgram of RNA was converted into cDNA and expression of group IB, IID and IVA PLA 2 was checked by qRT- PCR (Lightcycler 480, Roche diagnostics, Germany).

Table 2

Sequences of siRNAs

\begin{tabular}{|c|c|c|}
\hline S. No. & Name of target gene & Sequence of siRNAs \\
\hline \multirow[t]{2}{*}{1.} & PLA2 IB & Sense 5' CCCGUACACCCACACCUAU (dT)[dT] 3' \\
\hline & & Anti-sense 5' AUAGGUGUGGGUGUACGGG (dT)[dT] 3' \\
\hline \multirow[t]{2}{*}{2.} & PLA2 IID & Sense 5' CUUCUGACCUUCUGAAGCU (dT)[dT] 3' \\
\hline & & Anti-sense 5' AGCUUCAGAAGGUCAGAAG (dT)[dT] 3' \\
\hline \multirow[t]{2}{*}{3.} & PLA2 IVA & Sense 5' GACAUAAACCCUGUGUGGA (dT)[dT] 3' \\
\hline & & Anti-sense 5' UCCACACAGGGUUUAUGUC (dT)[dT] 3' \\
\hline \multirow[t]{2}{*}{4.} & Scrambled control & Sense 5' UUCUCCGAACGUGUCACGU (dT)[dT] 3' \\
\hline & & Anti-sense 5' ACGUGACACGUUCGGAGAA (dT)[dT] 3' \\
\hline
\end{tabular}

\section{Statistical analysis:}

The data were analyzed using the SPSS 16.0 software. All results were expressed as mean \pm SD. The differences in all data were assessed by one-way analysis of variance (ANOVA) by the Bonferroni test and 
nonparametric method such as Kurskali Wallice wherever required. The difference was taken as statistically significant at $p<0.05$.

\section{Results}

\section{Effects of various concentrations of $[B(a) P]$ on cell Viability:}

Figure 1 shows the effect of benzo(a)pyrene $[B(a) P]$ on the viability of HCT-15 (Fig. 1A) and HT-29 cells (Fig. 1B). Significant cytotoxicity in HCT-15 cells was observed at $1.0 \mu \mathrm{M}$ concentration of benzo(a)pyrene at 48 and $72 \mathrm{hr}(p=0.042)$. Whereas, at $24 \mathrm{hr}$ it was evident only at $100 \mu \mathrm{M}(\mathrm{p}=0.038)$. Cell survival at 1.0,10,50,100, and $200 \mu \mathrm{M}$ concentrations of $\mathrm{B}(\mathrm{a}) \mathrm{P}$ was found to be $88 \pm 6.9 \%, 97 \pm$ $5.5 \%, 92 \pm 9.5 \%, 84 \pm 3.1 \%$ and $58 \pm 7.6 \%$ at $24 \mathrm{hr} ; 83 \pm 3.6 \%, 80 \pm 4.0 \%, 78 \pm 1.5 \%, 73 \pm 3.6 \%$ and $54 \pm 1.7 \%$ at $48 \mathrm{hr}$; and $82 \pm 4.0 \%, 79 \pm 1.5 \%, 73 \pm 2.6 \%, 59 \pm 4.0 \%$ and $28 \pm 2.1 \%$ at $72 \mathrm{hr}$ respectively as compared to control in HCT-15 cells (Fig. 1A). Whereas, HT-29 cells were found to be in comparison to HCT-15 cells resistant to $\mathrm{B}(\mathrm{a}) \mathrm{P}$ as survival at $1.0,10,50,100$, and $200 \mu \mathrm{M}$ concentration was found to be $96 \pm 4.7 \%, 94$ $\pm 7.7 \%, 89 \pm 6.2 \%, 83 \pm 7.3 \%$ and $67 \pm 13.8 \%$ at $24 \mathrm{hr} ; 98 \pm 6.4 \%, 85 \pm 16.6 \%, 70 \pm 8.5 \%, 47 \pm 6.1 \%$ and $31 \pm$ $8.5 \%$ at $48 \mathrm{hr}$; and $100 \pm 6.9 \%, 84 \pm 13.1 \%, 63 \pm 14.4 \%, 39 \pm 11.2 \%$ and $20 \pm 2.6 \%$ at $72 \mathrm{hr}$ respectively as compared to control (Fig. 1B).

\section{Intracellular Ros Production:}

Total ROS production in HCT-15 and HT-29 cells by B(a)P concentrations at different time intervals is shown in Fig. 2. In HCT-15 cells, ROS production was found to be significantly increased $48 \mathrm{hr}$ after treatment of cells with varying concentrations of $B(a) P(0.1,1.0,10,50,100$ and $200 \mu M)$ respectively as compared to control (100\%) ( $p=)$ 0.036) (Fig. 2A). In HT-29 cells, total ROS production was found to be $157 \pm 39.1 \%, 254 \pm 48.1 \%, 274 \pm 18.3 \%, 444 \pm 39.5 \%, 455 \pm 46.0 \%$ and $279 \pm 34.4 \%$ at $24 \mathrm{hr}$ and, $214 \pm$ $43.7 \%, 255 \pm 29.8 \%, 255 \pm 38.5 \%, 350 \pm 37.2 \%, 300 \pm 14.1 \%$, and $232 \pm 38.8 \%$ at $48 \mathrm{hr}$ after treatment of cells at the above mentioned concentrations of $B(a) P$ respectively as compared to control $(100 \%)(p=$ 0.042) (Fig. 2B).

Mitochondrial ROS levels after treatment with varying $B(a) P$ concentrations $(0$ to $200 \mu M)$ in both the cell lines are shown in Fig. 3. In HCT-15 cells maximum the generation of ROS was observed at $50 \mu \mathrm{M}$ concentration of B(a)P (221\% vs $100 \%$ (control)). However, the generation of ROS declined almost to basal level after the treatment of cells at $200 \mu \mathrm{M}(p=0.028)$ (Fig. 3A). Whereas, ROS production in HT-29 cells was found to be at the peak after treatment with $1 \mu \mathrm{M}$ concentration of $\mathrm{B}(\mathrm{a}) \mathrm{P}$. However, the generation of ROS started declining after $10 \mu \mathrm{M}$ and reached to basal level at $200 \mathrm{mM}$ concentration $(\mathrm{p}=$ 0.032) (Fig. 3B).

The SOR production in HCT-15 cells after the exposure of various concentrations of B(a)P for $24 \mathrm{hr}$ and $48 \mathrm{hr}$ are shown in Fig. 4A. SOR production significantly decreased after the treatment of cells at $200 \mu \mathrm{M}$ of $B(a) P$ concentration as compared to the basal level $(p=0.022)$. We observed no change in the SOR 
production in HT-29 cells at $24 \mathrm{hr}$ after treatment with $\mathrm{B}(\mathrm{a}) \mathrm{P}$ concentrations. However, at $48 \mathrm{hr} \mathrm{SOR}$ production was significantly increased after treatment with $\mathrm{B}(\mathrm{a}) \mathrm{P}$ at $1 \mu \mathrm{M}$ to $50 \mu \mathrm{M}$ concentration as compared to basal level $(p=0.034)$ (Fig. 4B).

\section{Pla Mrna Expression In Hct-15 And Ht-29 Cells:}

mRNA expressions of secretory phospholipase $A_{2}\left(S_{P L A}\right)$, cytosolic phospholipase A2 $\left(C P L A_{2}\right)$ and independent phospholipase $A_{2}$ ( $\mathrm{iPLA}_{2}$ ) groups were evaluated in the cells after challenging them with selected concentrations of $B(a) P . P L A_{2}$ gene expression at $24 \mathrm{hr}$ and $48 \mathrm{hr}$ of treatment with the $\mathrm{B}(\mathrm{a}) \mathrm{P}$ in HCT-15 and HT-29 are shown in Fig. 5A and 5B respectively. Group IVC PLA $A_{2}$ was not detectable in HT-29 cells at the control level as well as after treatment with $B(a) P$ concentrations. Whereas, it was expressed in HCT-15 cells after treatment with $B(a) P$ concentrations. The other groups, like PLA $A_{2}$ IB of SPLA family, was upregulated significantly from $0.62 \pm 0.03$ (control) to $0.92 \pm 0.1,1 \pm 0.07$, and $1.1 \pm 0.15$ after treatment with $0.01,0.1$, and $1.0 \mu \mathrm{M} \mathrm{B}(\mathrm{a}) \mathrm{P}$ concentrations respectively in HT-29 cells at $48 \mathrm{hr}(\mathrm{p}=0.028)$ ). While such effects were not observed in HCT-15 cells after treatment with B(a)P at $48 \mathrm{hr}$. However, the IID $\mathrm{PLA}_{2}$ group was upregulated significantly. The relative gene expression after $\mathrm{B}(\mathrm{a}) \mathrm{P}$ treatment at $0.01,0.1$, and $1.0 \mu \mathrm{M} \mathrm{B}(\mathrm{a}) \mathrm{P}$ was upregulated significantly from $1.2 \pm 0.07$ (control) to $1.8 \pm 0.21,2 \pm 0.13$, and $2 \pm$ 0.15 respectively in HCT-15 cells $(p=0.025)$. While such effects were not observed in HT-29 cells after treatment with $\mathrm{B}(\mathrm{a}) \mathrm{P}$ at $48 \mathrm{hr}$. The relative gene expression of $\mathrm{PLA}_{2}$ group IVA was significantly upregulated after treatment with $0.01,0.1$, and $1.0 \mu \mathrm{M} \mathrm{B}(\mathrm{a}) \mathrm{P}$ from $0.9 \pm 0.1$ (control) to $1.4 \pm 0.19,1.8 \pm$ 0.24 , and $1.8 \pm 0.27$ respectively in HCT-15 cells at $48 \mathrm{hr}(\mathrm{p}=0.041)$. All values are given in the form of a grey value of densitometry analysis by image $\mathrm{J}$ software. Levels of mRNA expression of III, IVB, IVC, VI, X, aiPLA $_{2}$ and iPLA ${ }_{2}$ groups were not affected in the cells after treatment with B(a)P. (Fig. 5A and 5B).

\section{Effect of silencing of IB, IID, and IVA PLA2 by specific PLA2-siRNA in $B(a) P$ treated colon cells:}

The upregulation of IB, IID and IVA PLA ${ }_{2}$ gene expression in the presence of $B(a) P$ was inhibited by siRNA of IB, IID and IVA PLA 2 gene in HCT-15 and HT-29 colon cells.

\section{Silencing of gene expression in HT-29 and HCT-15 cell lines by siRNA:}

Relative gene expression (mean \pm SD) of group IB at mRNA levels in siRNA (IB) without and with $0.1 \mu \mathrm{M}$ $B(a) P$ was found to be, significantly reduced as compared with scrambled siRNA $(P=0.035)$ in HT-29 cells (Fig. 6A). Relative mRNA expressions of IID in siRNA (IID) without and with $0.1 \mu \mathrm{M} \mathrm{B}(\mathrm{a}) \mathrm{P}$ were found to be significantly reduced $(p=0.025)$ as compared to scrambled controls in HCT-15 (Fig. 6B). Relative gene expression of group IVA at mRNA levels in siRNA (IVA) without and with $0.1 \mu \mathrm{M} \mathrm{B}(\mathrm{a}) \mathrm{P}$ concentration was found to significantly down-regulated $(p=0.021)$ in comparison to scrambled controls in HCT-15 


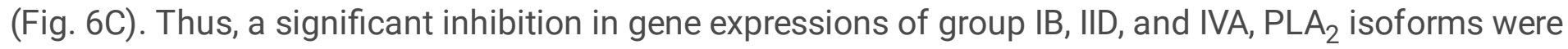
observed in the presence of siRNA of specific PLA 2 gene $(p<0.05)$.

\section{Effect of group IB, IID, and IVA PLA ${ }_{2}$ gene silencing}

\section{Cell Viability:}

Effects of $B(a) P$ on cell viability after silencing the specific $\mathrm{PLA}_{2}$ genes are shown in Fig. 7 at $48 \mathrm{hr}$. Figure-7A shows cell viability in group IB PLA ${ }_{2}$ transfected cells using IB siRNA. Viability of cells in scrambled siRNA control and siRNA (IB) without and with $0.1 \mu \mathrm{M} \mathrm{B}(\mathrm{a}) \mathrm{P}$ were found to be comparable respectively as compared to scrambled control in HT-29 cells (Fig. 7A). The percentage of cell viability after knockdown with IID PLA 2 siRNA or scrambled siRNA control and siRNA (IID) without and with $0.1 \mu \mathrm{M} \mathrm{B}(\mathrm{a}) \mathrm{P}$ were found to be not significantly reduced as compared to scrambled control in HCT-15 cells (Fig. 7B). The cell viability in HCT-15 cells after the suppression of group IVA PLA 2 gene using siRNA of scrambled siRNA control and siRNA (IVA) without and with $0.1 \mu \mathrm{M} \mathrm{B}(\mathrm{a}) \mathrm{P}$ were found to be comparable as compared to scrambled control (Fig. 7C). It was worth noting that values after treatment with $B(a) P$ were statistically non significant to scrambled control.

\section{Intracellular Ros:}

ROS formation in the presence of group IB, IID and IVA siRNA in both cell lines at $48 \mathrm{hr}$ is shown in Fig. 8 . Total ROS production in scrambled siRNA control and siRNA (IB) without and with $0.1 \mu \mathrm{M}$ of $\mathrm{B}(\mathrm{a}) \mathrm{P}$ in $\mathrm{HT}-$ 29 cells were found to be $101 \pm 3.1 \%, 86 \pm 5.5 \%$ and $106 \pm 7.3 \%$ respectively (Fig. 8A). ROS production in HCT-15 cells in the presence of scrambled siRNA control and siRNA (IID) without and with $0.1 \mu \mathrm{M}$ of $\mathrm{B}$ (a)P siRNA (IID) were found to be $106 \pm 6.6 \%, 97 \pm 5.1 \%$ and $88 \pm 4.6 \%$ respectively (Fig. 8B). Whereas, ROS production in the presence of group IVA siRNA with exposure to $0.1 \mu \mathrm{M} \mathrm{B}(\mathrm{a}) \mathrm{P}$ were $109 \pm 10.3 \%, 104$ $\pm 4.1 \%$, and $147 \pm 6.9 \%$ in scrambled siRNA control and siRNA (IVA) without and with $0.1 \mu \mathrm{M}$ of $\mathrm{B}(\mathrm{a}) \mathrm{P}$ respectively as compared to scrambled control in HCT-15 cells (Fig. 8C). A statistically significant increase $(p=0.014)$ in ROS production was found only in IVA transfected cells when challenged with $0.1 \mu \mathrm{M} \mathrm{B}(\mathrm{a}) \mathrm{P}$. Figure $8(\mathrm{D}, \mathrm{E}$, and $\mathrm{F}$ ) shows mitochondrial ROS production after down-regulation of the $\mathrm{PLA}_{2}$ gene using siRNA and treating the cells with $0.1 \mu \mathrm{M} \mathrm{B}(\mathrm{a}) \mathrm{P}$ at $48 \mathrm{hr}$. ROS production in HT-29 cells transfected with group IB PLA 2 gene using siRNA and treated to $0.1 \mu \mathrm{M} \mathrm{B}(\mathrm{a}) \mathrm{P}$ was $89 \pm 6.4 \%, 81 \pm 3.7 \%$, and $89 \pm 3.4 \%$ in scrambled siRNA control and siRNA (IB) without and with $0.1 \mu \mathrm{M}$ of $\mathrm{B}(\mathrm{a}) \mathrm{P}$ respectively

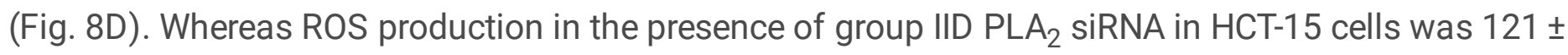
$2.8 \%, 97 \pm 10.3 \%$ and $92 \pm 8.6 \%$ in scrambled siRNA control and siRNA (IID) without and with $0.1 \mu \mathrm{M}$ of $\mathrm{B}(\mathrm{a}) \mathrm{P}$ respectively (Fig. 8E). On the other hand, ROS production in the presence of group IVA siRNA with exposure to $0.1 \mu \mathrm{M} \mathrm{B}(\mathrm{a}) \mathrm{P}$ was $104 \pm 12.5 \%, 99 \pm 5.2 \%$, and $96 \pm 4.2 \%$ in scrambled siRNA control and siRNA (IVA) without and with $0.1 \mu \mathrm{M}$ of $\mathrm{B}(\mathrm{a}) \mathrm{P}$ respectively in HCT-15 cells (Fig. 8F). However, all the 
values in the experimental groups mentioned above were statistically non-significant to scrambled control.

\section{Sor Production:}

Relative SOR production in the presence of group IB, IID and IVA siRNA in both cell lines at $48 \mathrm{hr}$ is shown in Fig. 9. Relative SOR production in HT-29 cells transfected with group IB PLA 2 gene siRNA treated with $0.1 \mu \mathrm{M} \mathrm{B}(\mathrm{a}) \mathrm{P}$ in scrambled siRNA control and siRNA (IB) without and with $0.1 \mu \mathrm{M}$ of $\mathrm{B}(\mathrm{a}) \mathrm{P}$ were found to be $92 \pm 4.9 \%, 103 \pm 9.6 \%$ and $116 \pm 3.5 \%$ respectively (Fig. $9 A$ ). Whereas, SOR production in scrambled siRNA control and siRNA (IID) without and with $0.1 \mu \mathrm{M}$ of $\mathrm{B}(\mathrm{a}) \mathrm{P}$ was $91 \pm 8.0 \%, 86 \pm 6.7 \%$, and $90 \pm 3.6 \%$ respectively in HCT-15 cells (Fig. 9B). However, the SOR production in HCT-15 cells in the presence of siRNA (IVA) was $96 \pm 12.0 \%, 73 \pm 10.7 \%$ and $69 \pm 13.0 \%$ in scrambled siRNA control and siRNA (IVA) without and with $0.1 \mu \mathrm{M}$ of $\mathrm{B}(\mathrm{a}) \mathrm{P}$ respectively (Fig. 9C). Like other parameters such as cell viability, ROS, mitochondrial ROS, etc in this case also the changes were non-significant to scrambled control.

\section{Discussion}

CS continues to remain one of the most important health hazards and it contributes extensively to many diseases including respiratory disorders characterized by inflammatory changes in the lungs $[9,10]$. It is involved in many other cancers like pharynx, larynx, esophagus, etc. various studies also suggested the relationship between smoking and stomach, liver and colon cancer [11, 12]. However, the molecular and cellular mechanism involved in the pathogenesis of smoking-related colon cancer remains unknown.

CS is a very complex, multi-factorial stimulus with over 5300 identified [13]. Approximately 100 carcinogens, co-carcinogens, mutagens, and/or tumor promoters are present in CS [14]. One of the most prominent carcinogens in burned as well as, unburned tobacco, is benzo(a) [15]. The complex changes in cellular functions, morphology and gene expression caused by CS constituents that are initiators as well as promoters of carcinogenesis [16], involve a combination of direct and indirect effects on cells and their components. We found that treatment with $\mathrm{B}(\mathrm{a}) \mathrm{P}$ resulted in a significant change in cell shape and size in both the cell lines (HCT-15 and HT-29 cells). There was prominent fragmentation, loss of cohesiveness, irregular shape and the cells appeared in clumps. Our present study is in check this word with an earlier report, on MCF-10A and MCF-12A cell lines which also showed these cellular changes after CSC treatment. These morphological changes may be due to multiples factors like altered cell membrane integrity caused by increased formation of ROS leading to changes in cytotoxicity, proliferation and apoptosis.

Cytotoxicity, an important factor in understanding the mechanism of action of chemicals on cells and tissues, may modulate the activity of other agents, including free radicals, oxidants, irritants and genotoxins [17]. These intracellular moieties have been reported to induce adverse effects in the body [18]. In this study, we observed that no cytotoxic effects of $B(a) P$ at concentrations below $1 \mu \mathrm{M}$ in HCT-15 
and below $50 \mu \mathrm{M}$ in HT-29 cells, but at higher concentrations, the cell viability decreased significantly. Similar observations have been reported earlier on the effects of B(a)P in other cell lines [19].

Cellular levels of ROS reflect a delicate balance between ROS production and detoxification. Despite the existence of such well-coordinated cellular ROS detoxification systems, the uncontrolled ROS production may overwhelm these defense mechanisms. Many previous studies have shown that aqueous cigarette tar extracts increase cellular production of ROS $[20,21]$ leading to increased pro-inflammatory gene expressions [22]. As cells respond to various agents and mediate the regulation of ROS through different mechanisms of $\mathrm{H} 2 \mathrm{O} 2$, superoxide and mitochondrial ROS generation. It was of interest to elucidate the main mechanism of ROS mediated damage towards the B[a]P in the colon cells. Hence we used various fluorescent probes that detect the intracellular $\mathrm{H}_{2} \mathrm{O}_{2}$ using DCFH-DA, superoxide using DHE and mitochondrial ROS using DHR123. Our results clearly show that PLA2 IVA is identified in the intracellular $\mathrm{H} 2 \mathrm{O} 2$ mediated oxidative stress. In this study, we have found that $\mathrm{B}(\mathrm{a}) \mathrm{P}$ induced intracellular ROS in both the colon cell lines (HCT-15 and HT-29). However, the extent of ROS production was more in HT-29 cells than in HCT-15 cells. Interestingly the induction of ROS, in HT-29 cells which had the origin from colorectal, human primary carcinoma of the colon was more active in producing ROS [23]. As intracellular ROS could function upstream or downstream of the mitochondria, we also determined the mitochondrial ROS production in these cells after exposure with B(a)P. It was found that the extent of generation of ROS in mitochondria of HT-29 cells was less as compared to HCT-15 cells. Besides this the extent of mitochondrial ROS generation in HT-29 cell was much less than the overall stimulation whereas, in HCT15 cells the increase in overall and mitochondrial production of ROS was much less than in HT-29 cells. The possible explanation for such an observation could be the variation in mitochondrial antioxidant defense (enzymatic and non-enzymatic) system in the two cell lines, one of which (HT-29) is more resistant than the other (HCT-15) to the toxic materials.

Another pathway of regulating the superoxide radicals is through ubiquinol $\left(\mathrm{QH}_{2}\right)$ which has been shown to act as a reducing agent in the elimination of various peroxides in the presence of succinate [24]. Though like total ROS, SOR production by $\mathrm{B}(\mathrm{a}) \mathrm{P}$ was more in HT-29 than HCT-15 cells, the mitochondrial ROS production was more in HCT-15 cells. This finding indicates of better antioxidant status of HT-29 cells and is likely to be related to the stability of cells in response to toxic material B(a)P. If we closely look at the cell viability and ROS generation at the concentrations of Benzo pyrene used, both the cell lines showed the ROS generation using all the fluorescent dyes. However, the concentrations at which both the cell lines showed ROS generation was at 0.1uM for DCFH-DA and DHR123. It is clear from this result that the initiation of ROS starts at $0.1 \mathrm{uM}$ but to have the toxicity effect the dose of $0.1 \mu \mathrm{M} \mathrm{B}[\mathrm{a}] \mathrm{P}$ is not sufficient to elicit the damaging effect and only happens beyond the dose of $1 \mu \mathrm{M}$. In this study we observed that the exposure to $\mathrm{B}(\mathrm{a}) \mathrm{P}$ in colon epithelial cells induced an increase in the expression of phospholipase $\mathrm{A}_{2}$. SPLA 2 isoforms produce inflammatory mediators that stimulate the expression of ICAM-1. Recently several studies have looked beyond the role of phospholipase enzymes in inflammation to probe their contribution to the pathogenesis of cancer [25-27]. As per our knowledge there is no study that has determined the status of $\mathrm{PLA}_{2}$ isoforms expression in colon cells after exposure with $\mathrm{B}(\mathrm{a}) \mathrm{P}$. 
There are some studies that have reported the expression of various $\mathrm{PLA}_{2}$ isoforms in some cancers including colon cancer. However, the majority of these studies have looked at the expression of CPLA 2 only. Our study is different from all the previous studies as we have evaluated the expression of all PLA 2 isoforms as well as their modulation with $\mathrm{B}(\mathrm{a}) \mathrm{P}$. In this study, expression of PLA $\mathrm{A}_{2}$ isoforms in both cell lines were treated with $B(a) P$, induction in the expression of PLA $A_{2}$ isoforms was different in HCT-15 and HT-29 cells. Group IVC PLA 2 was not expressed in HT-29 cells at the control level as well as after treatment with $B(a) P$. Whereas, it was expressed in HCT-15 cells after treatment with $B(a) P$. PLA $A_{2}$ IID and IVA group of $\mathrm{SPLA}_{2}$ family was upregulated significantly in treated groups when compared to control in HCT-15 cells whereas group IB PLA $A_{2}$ increased significantly with $B(a) P$ treatment in HT-29 cells. Levels of mRNA expression of III, IVB, IVC, VI, X, aiPLA ${ }_{2}$ and iPLA $_{2}$ groups were not affected in the cells after treatment with $B(a) P$.

Many previous studies documented the PLA $\mathrm{s}_{2}$ such as $\mathrm{CPLA}_{2}, \mathrm{SPLA}_{2}$ group IIA, sPLA 2 group IID and $\mathrm{SPLA}_{2}$ group $X$ has been involved in colon tumor development $[28,29]$. Our findings are similar to that of Valentine et al., 2000 [30] to some extent, wherein they found over-expression of $\mathrm{CPLA}_{2}$ in $49 \%$ of colon carcinomas patients as well as in four colon cancer cell lines. These results coincide with the elevated expression of $\mathrm{CPLA}_{2} \mathrm{a}$ in human colon adenocarcinoma [31]. On the other hand, $\mathrm{CPLA}_{2}$ expression has been reported to be was diminished in azoxymethane-induced mouse colon tumors and knock-out of $\mathrm{CPLA}_{2}$ enhanced colon tumor development [32]. But effects of PLA $-\mathrm{A}_{2}$ nnockdown observed in this study on CSC- and B(a)P-induced changes may be due to reversal of the process of cell morphology, cell viability, cell proliferation, cell membrane integrity, cell apoptosis, ROS production, mitochondrial ROS production and SOR formation in transfected cells by specific PLA 2 siRNA as well as in cells treated with selected concentration of $\mathrm{B}(\mathrm{a}) \mathrm{P}$ in HCT-15 and HT-29 cells. The underlying molecular mechanism involved in this process appears to be through sPLA 2 (group IID) and cPLA 2 (group IVA) in HCT-15 cells, whereas it occurs through $\mathrm{SPLA}_{2}$ (group IB) in HT-29 cells. This observation clearly indicates that $\mathrm{SPLA} \mathrm{A}_{2}$ isoforms are commonly affected $\mathrm{PLA}_{2}$ in both these cell lines and inhibition of this isoform by the specific agents may play an important role in arresting the growth of colon cancer cells.

\section{Conclusion}

sPLA $A_{2}$ appears to be the most common form of $\mathrm{PLA}_{2}$ playing a role in the deleterious effects of $\mathrm{B}(\mathrm{a}) \mathrm{P}$ in HCT-15 and HT-29 colon cells.

\section{List Of Abbreviations}

$\mathrm{B}(\mathrm{a}) \mathrm{P} ;$ Benzo(a)pyrene

cPLA2; Cytosolic phospholipase A2

CRC; Colorectal cancer

Page $12 / 22$ 
CS; Cigarette smoke

CSC; Cigarette smoke condensate

iPLA2; Independent phospholipase A2

MTT; 3-(4, 5- dimethylthiazol-2-yl)-diphenyltetrazolium bromide

PBS; Phosphate buffer saline

PLA $_{2} ;$ Phospholipase $A_{2}$

ROS; Reactive oxygen species

SOR; Superoxide radicals

sPLA; ; Secretory phospholipase $A_{2}$

\section{Declarations}

Ethical Approval and Consent to participate: Not applicable

Consent for publication: Not applicable.

Availability of data and material: Detail description of observations is mentioned in the result section.

Competing interests: The authors declare that they have no competing interests.

Funding: Indian Council of Medical Research, Govt. of India, New Delhi, for the award of Senior Research Fellowship (IRIS ID: 2010-09550) to Sanjeev Kumar Sharma. However, no funding is available for the project and publication.

Authors' contributions: SKS: Designing and executed the experiments as well as written the manuscript; SKY \& US: Helped in performing the experiments; PV: supervised the experiments, SVR \& KLK: Designed and supervised the whole experiments. All authors read and approved the final manuscript.

Acknowledgments: Authors would like to acknowledge Indian Council of Medical Research, Govt. of India, New Delhi, for the award of Senior Research Fellowship (IRIS ID: 2010-09550) to Sanjeev Kumar Sharma.

\section{References}

1. Ferlay J, Shin HR, Bray F, Forman D, Mathers C, Parkin DM. Estimates of worldwide burden of cancer in 2008: GLOBOCAN 2008. Int J Cancer. 2010;127:2893-917.

2. Chan EWC, Soon CY, Tan JBL, Wong SK, Hui YW. Ursolic acid: An overview on its cytotoxic activities against breast and colorectal cancer cells. J Integr Med. 2019;17:155-60. 
3. Agen B, Maas LM, Zwingmann IH, Schooten FJV, Kleinjans JCS. B(a)P adduct formation and induction of human epithelial lung cell transformation. Environ Mol Mutagen. 2001;30:287-92.

4. Steiner MR, Clark MA, Bomalaski JS. Inhibitors of phospholipase A2 and eicosanoid biosynthesis in cancer. Drugs News Perspectives. 1994;7:344-51.

5. Sharma U, Pal D, Singh SK, Nandita K, Prasad R. Reduced L/B/K alkaline phosphatase gene expression in renal cell carcinoma: plausible role in tumorigenesis. Biochimie2014;104:27-35.

6. Dikalov SI, Harrison DG. Methods for detection of mitochondrial and cellular reactive oxygen species. Antioxid Redox Signal. 2014;20:372-82.

7. Sharma U, Pal D, Prasad R. A novel role of alkaline phosphatase in the ERK1/2 dephosphorylation in renal cell carcinoma cell lines: A new plausible therapeutic target. Biochimie. 2014;107B:406-09.

8. Pal D, Sharma U, Singh SK, Nandita K, Prasad R. Over-expression of telomere binding factors (TRF1 \& TRF2) in renal cell carcinoma and their inhibition by using siRNA induce apoptosis, reduce cell proliferation and migration invitro. PLOS One. 2015;10:e0115651.

9. Maestrelli P, El Messlemani AH, De Fina O, et al. Increased expression of heme oxygenase (HO)-1 in alveolar spaces and HO-2 in alveolar walls of smokers. Am J Respir Crit Care Med. 2001;164:150813.

10. Lavigne MC, Eppihimer MJ. Cigarette smoke condensate induces MMP-12 gene expression in airwaylike epithelia. BiochemBiophys Res Commun. 2005;330:194-203.

11. Edgar SL, Liu Y-N, Ye, Vivian Y, Shin, et al. Cigarette smoke exposure increases ulcerative colitisassociated colonic adenoma formation in mice. Carcinogenesis. 2003;24:1407-13.

12. Wong HPuiS, Yu L. Emily Kai Yee Lam, Emily Kin Ki Tai, William Ka Kei Wu, Chi-Hin Cho. Nicotine Promotes Colon Tumor Growth and Angiogenesis through b-Adrenergic Activation. Toxicol Sci. 2007;97:279-87.

13. Perfetti AR. a. TA. The Chemical Components of Tobacco and Tobacco Smoke. Boca Raton: CCRC Press. Taylor and Francis Group; 2009.

14. Smith CJ, Perfetti TA, Garg R, Hansch C. IARC carcinogens reported in cigarette mainstream smoke and their calculated log P values. Food Chem Toxicol. 2003;41:807-17.

15. Hoffmann D, Wynder EL. Selective reduction of the tumorigenicity of tobacco smoke. Experimental approaches. Natl Cancer Inst Monogr. 1968;28:151-72.

16. Wu WK, Cho $\mathrm{CH}$. The pharmacological actions of nicotine on the gastrointestinal tract. J Pharmacol Sci. 2004;94:348-58.

17. Bombick DW, Ayres PH, Putnam K, Bombick BR, Doolittle DJ. Chemical and biological studies of a new cigarette that primarily heats tobacco. Part 3. In vitro toxicity of whole smoke. Food Chem Toxicol. 1998;36:191-7.

18. Waldren CA, Vannais DB, Knowlton MS, Domenico KK, Smith CJ, Doolittle DJ. The role of glutathione in the toxicity of smoke condensates from cigarettes that burn or heat tobacco. Free RadicBiol Med. 2001;30:1400-6. 
19. Bishop E, Theophilus EH, Fearon IM. In vitro and clinical studies examining the expression of osteopontin in cigarette smoke-exposed endothelial cells and cigarette smokers. BMC Cardiovasc Disord. 2012;12:75.

20. Haller H. Endothelial function. General considerations Drugs. 1997;53:1-10.

21. Ambrose JA, Barua RS. The pathophysiology of cigarette smoking and cardiovascular disease: an update. J Am Coll Cardiol. 2004;43:1731-7.

22. Bagi Z, Koller A. Lack of nitric oxide mediation of flow-dependent arteriolar dilation in type i diabetes is restored by sepiapterin. J Vasc Res. 2003;40:47-57.

23. Von Kleist S, Chany E, Burtin P, King M, Fogh J. Immunohistology of the antigenic pattern of a continuous cell line from a human colon tumor. J Natl Cancer Inst. 1975;55:555-60.

24. Eto $Y$, Kang D, Hasegawa E, Takeshige K, Minakami S. Succinate-dependent lipid peroxidation and its prevention by reduced ubiquinone in beef heart submitochondrial particles. Arch BiochemBiophys. 1992;295:101-6.

25. Mauchley D, Meng X, Johnson T, Fullerton DA, Weyant MJ. Modulation of growth in human esophageal adenocarcinoma cells by group lla secretory phospholipase A(2). J Thorac Cardiovasc Surg. 2010;139:591-99.

26. Sadaria MR, Meng X, Fullerton DA, et al. Secretory phospholipase A2 inhibition attenuates intercellular adhesion molecule-1 expression in human esophageal adenocarcinoma cells. Ann Thorac Surg. 2011;91:1539-45.

27. Yu JA, Sadaria MR, Meng X, et al. Lung cancer cell invasion and expression of intercellular adhesion molecule-1 (ICAM-1) are attenuated by secretory phospholipase A2 inhibition. J Thorac Cardiovasc Surg. 2012;143:405-11.

28. Morioka $Y$, Ikeda $M$, Saiga A, et al. Potential role of group $X$ secretory phospholipase $A(2)$ in cyclooxygenase-2-dependent PGE(2) formation during colon tumorigenesis. FEBS Lett. 2000;487:262-6.

29. Murakami M, Yoshihara K, Shimbara S, et al. Group IID heparin-binding secretory phospholipase A(2) is expressed in human colon carcinoma cells and human mast cells and up-regulated in mouse inflammatory tissues. Eur J Biochem. 2002;269:2698-707.

30. Valentin E, Lambeau G. Increasing molecular diversity of secreted phospholipases A(2) and their receptors and binding proteins. BiochimBiophys Acta. 2000;1488:59-70.

31. Lim SC, Cho H, Lee TB, et al. Impacts of cytosolic phospholipase A2, 15-prostaglandin dehydrogenase, and cyclooxygenase-2 expressions on tumor progression in colorectal cancer. Yonsei Med J. 2010;51:692-9.

32. Ilsley JN, Nakanishi M, Flynn C, et al. Cytoplasmic phospholipase A2 deletion enhances colon tumorigenesis. Cancer Res. 2005;65:2636-43.

\section{Figures}




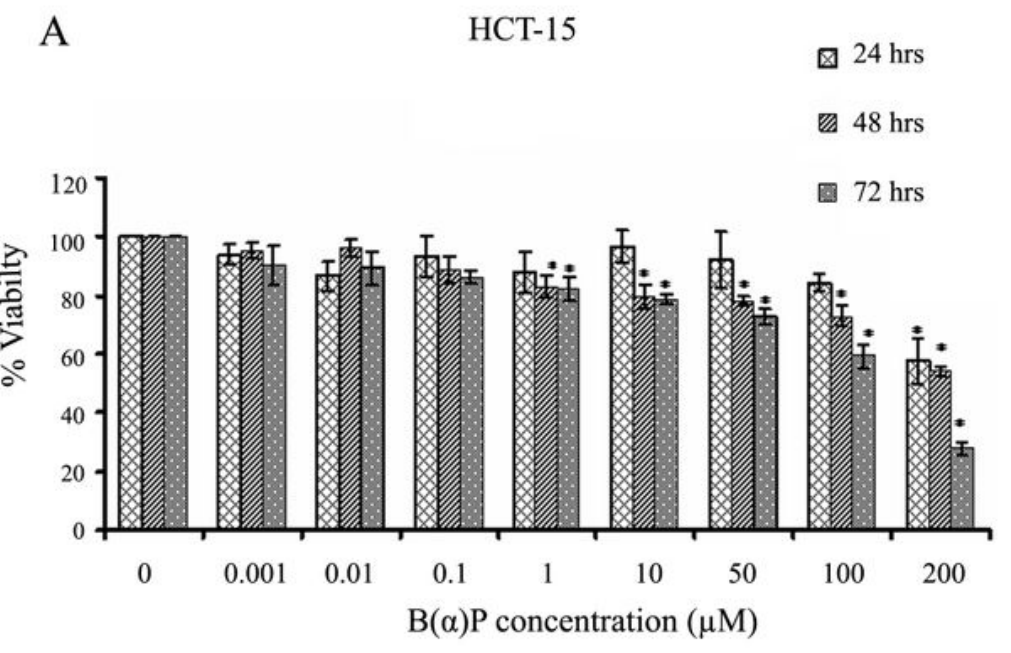

B

HT-29

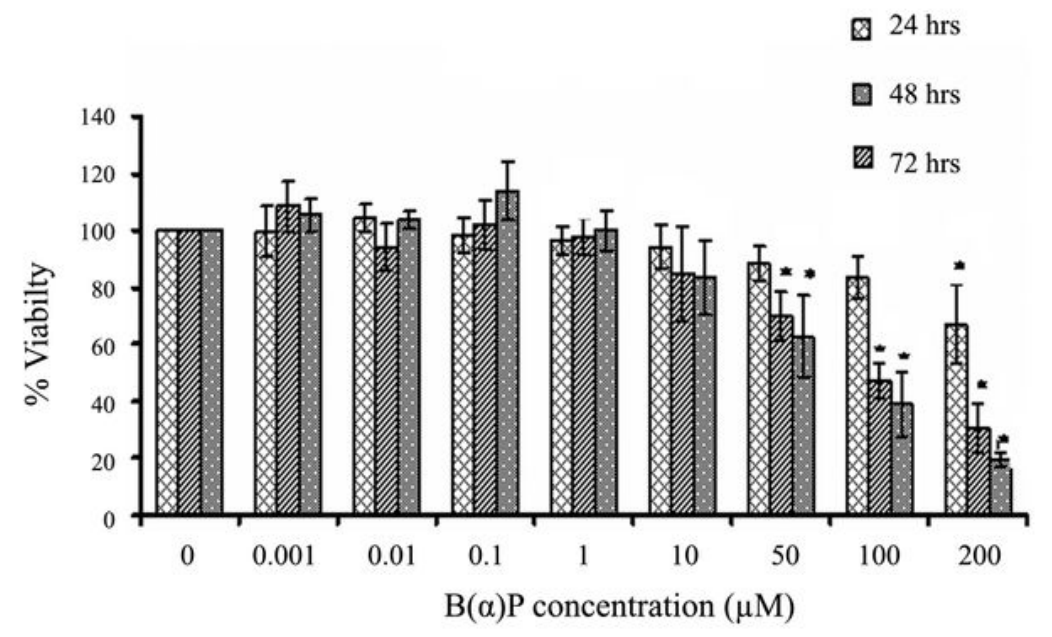

Figure 1

Effect of $B(a) P$ treatment on cell viability (MTT assay) in HCT-15 cells (A) and HT-29 cells (B). Both the cell lines were treated with different concentrations of $B(a) P$ for 24,48 and 72 hours. Results are expressed as mean $\pm S D$ of three assays. ${ }^{*} p<0.05 ;{ }^{*} B(a) P$ treated cells compared with respective controls. 


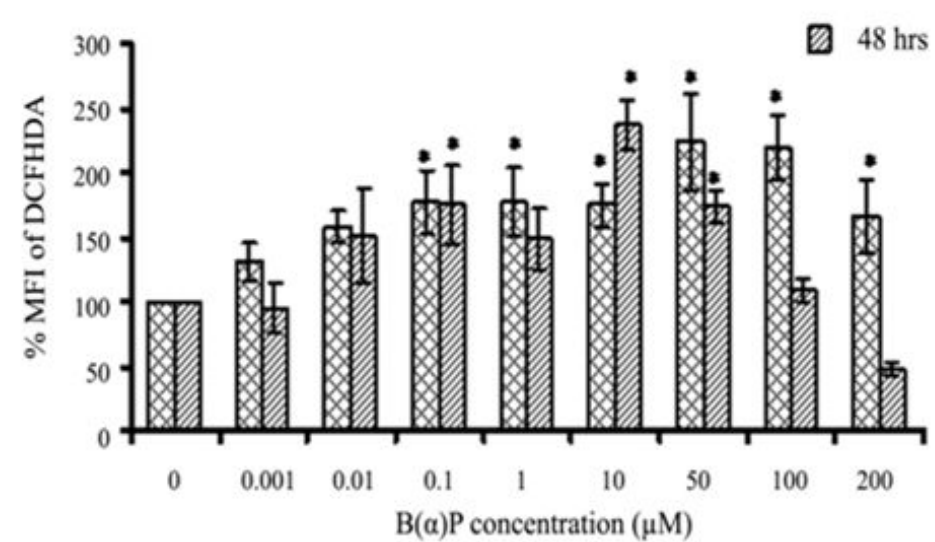

$\mathbf{A}$

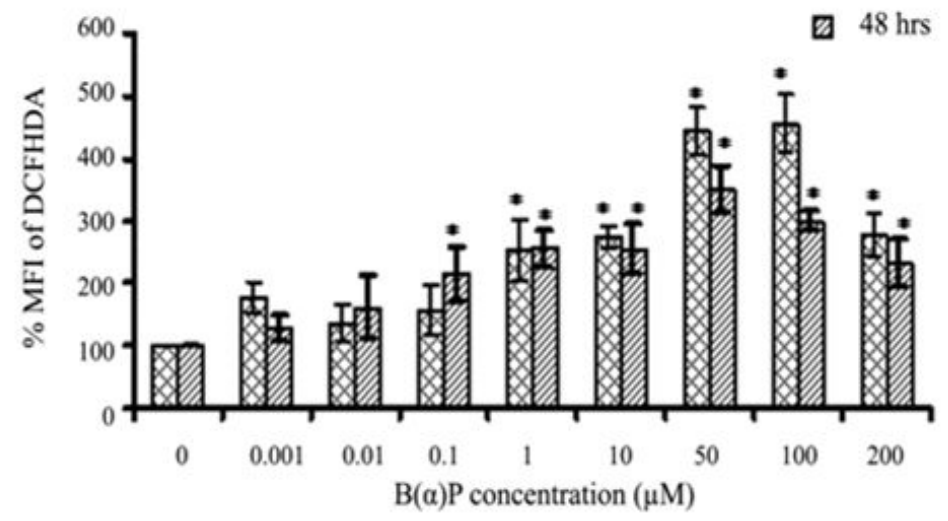

B

\section{Figure 3}

Effect of B(a)P treatment on ROS production (by DCFH-DA fluorescence dye) in HCT-15 cells (A) and HT29 cells (B). Both the cell lines were treated with different concentrations of B(a)P for 24 and 48 hours including 30 minutes with fluorescence dye at the end phase. Cells were then washed with sterile PBS, and deadhered for final analysis. Results are expressed as mean $\pm S D$ of three assays. ${ }^{*} p<0.05 ;{ }^{*} B(a) P$ treated cells compared with respective controls. 


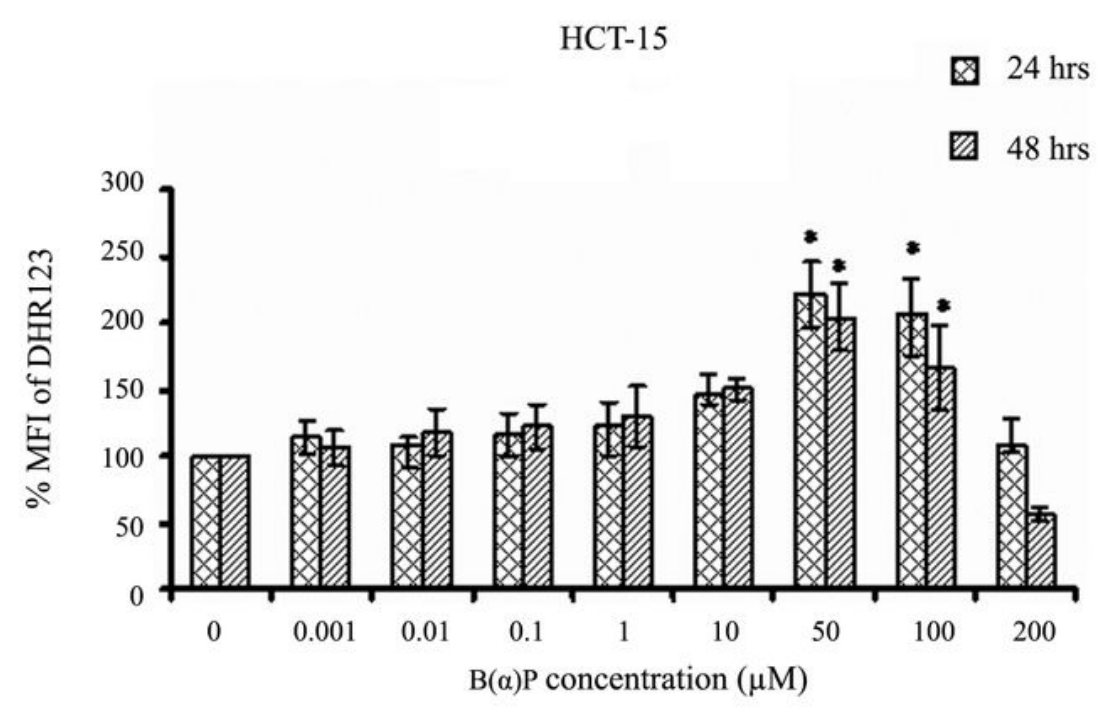

A

HT-29

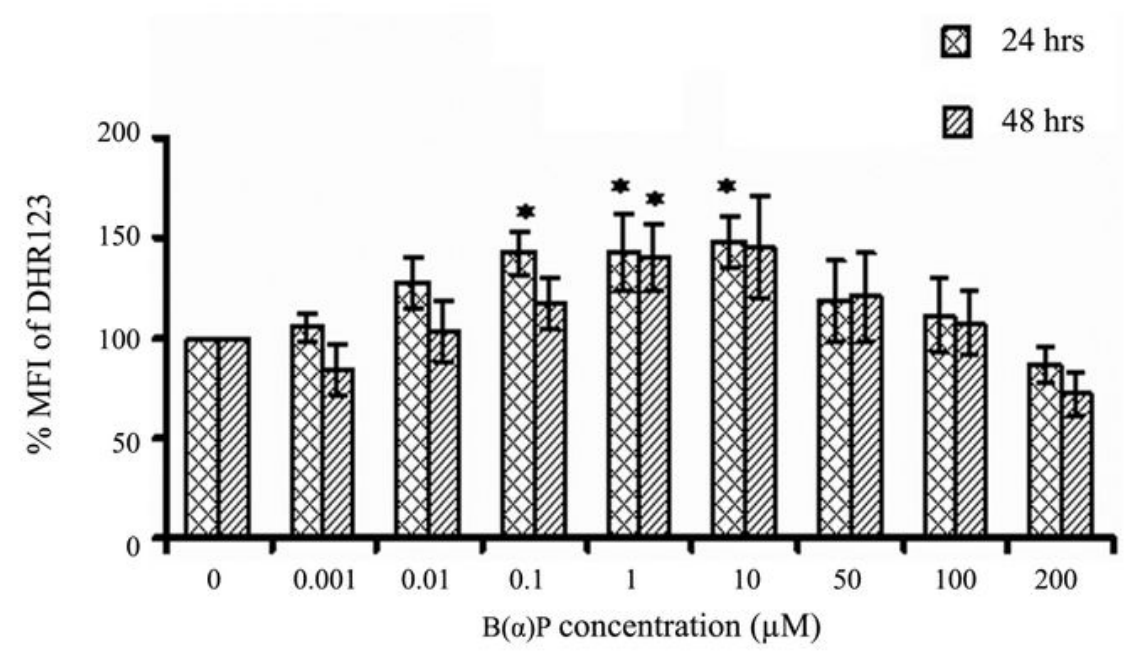

B

\section{Figure 5}

Effect of B(a)P treatment on mtROS production (by DHR123 fluorescence dye) in HCT-15 cells (A) and HT29 cells $(B)$. Both the cell lines were treated with different concentrations of $B(a) P$ for 24 and 48 hours including 30 minutes with fluorescence dye at the end phase. Cells were then washed with sterile PBS, and deadhered for final analysis. Results are expressed as mean $\pm S D$ of three assays. ${ }^{*} p<0.05$; ${ }^{*} B(a) P$ treated cells compared with respective controls. 
HCT-15
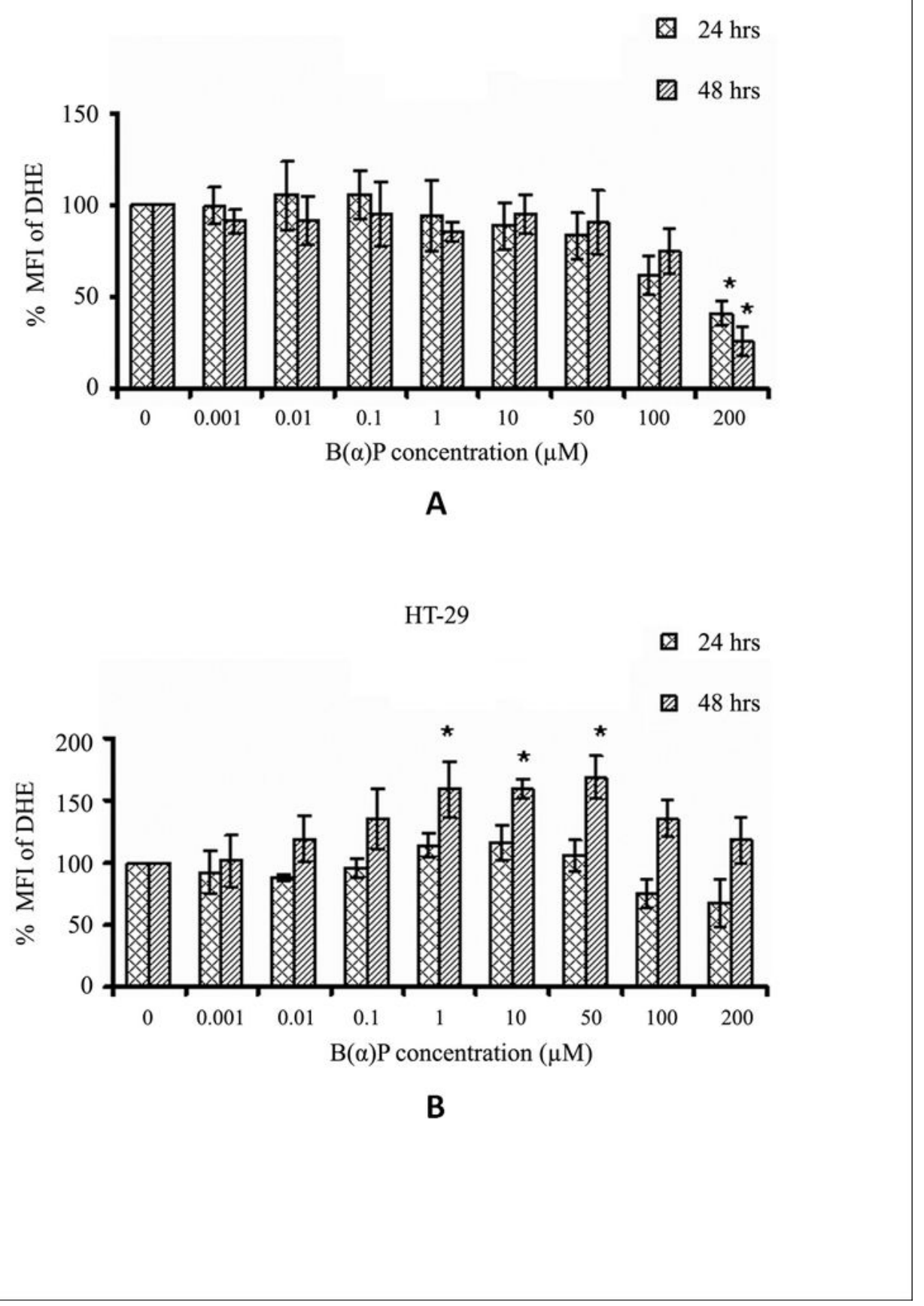

Figure 7

Effect of B(a)P treatment on SOR production (by DHE fluorescence dye) in HCT-15 cells (A) and HT-29 cells $(B)$. Both the cell lines were treated with different concentrations of $B(a) P$ for 24 and 48 hours including 30 minutes with fluorescence dye at the end phase. Cells were then washed with sterile PBS, and de-adhered for final analysis. Results are expressed as mean $\pm S D$ of three assays. ${ }^{*}<<0.05 ;{ }^{*} B(a) P$ treated cells compared with respective controls. 
A

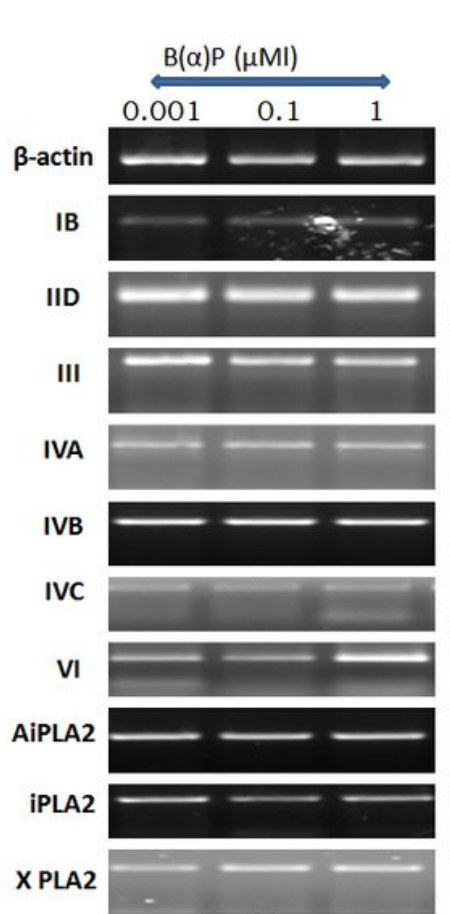

$24 \mathrm{hrs}$

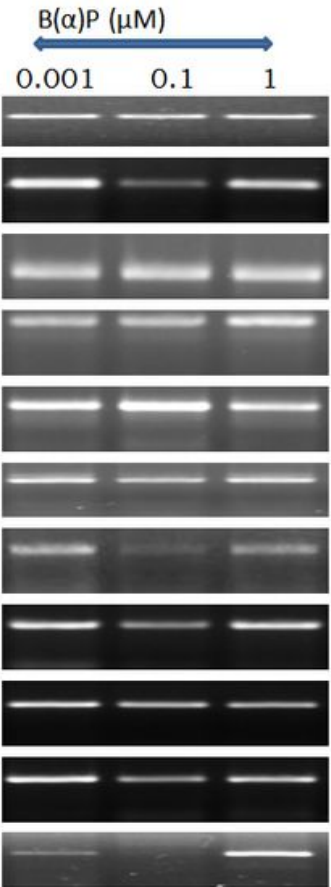

$48 \mathrm{hrs}$
B

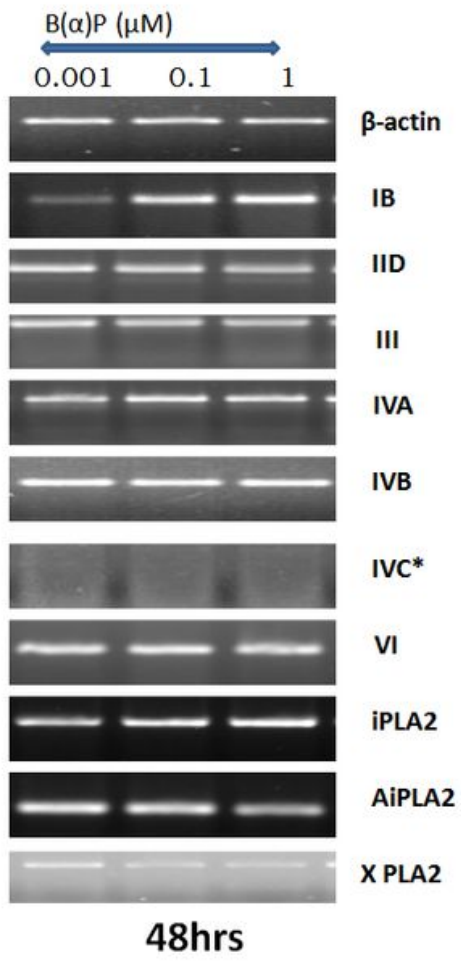

$24 \mathrm{hrs}$

$48 \mathrm{hrs}$

\section{Figure 9}

mRNA expression of different groups of isoforms at constitutive level and after treatment with $\mathrm{B}(\mathrm{a}) \mathrm{P}$ for different times ( 24 and 48 hours) in HCT-15 cells (A) and HT-29 cells (B). $\beta$-actin was used as an internal control for normalization of mRNA levels. Experiments were done in triplicates.

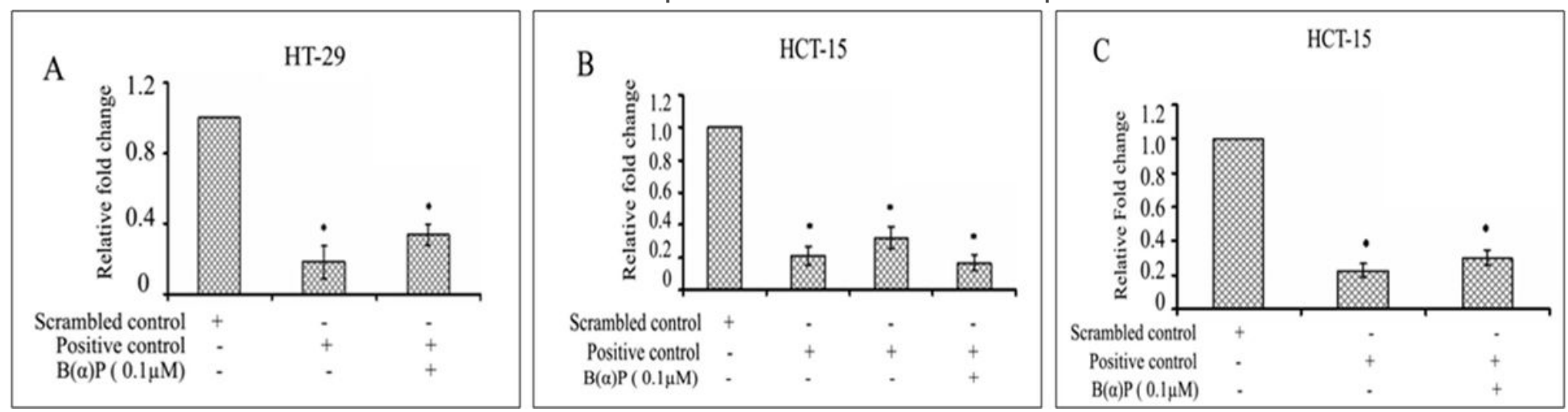

\section{Figure 11}

Real Time PCRanalysis of (A) group IB PLA2 in siRNA transfected HT-29 cells (B) Group IID PLA2 transfected HCT-15 cells (C) Group IVA PLA2 transfected HCT-15 cells with scrambled control, positive control and positive control along with $\mathrm{B}(\mathrm{a}) \mathrm{P}$ exposure for 48 hours. $\beta$-actin was used as an internal control for normalization of mRNA levels. Relative expression represented by fold change. Results are expressed as mean $\pm S D$ of three assays. ${ }^{*} p<0.05$; ${ }^{*}$ positive control cells and $B(a) P$ treated cells compared with scrambled control. 

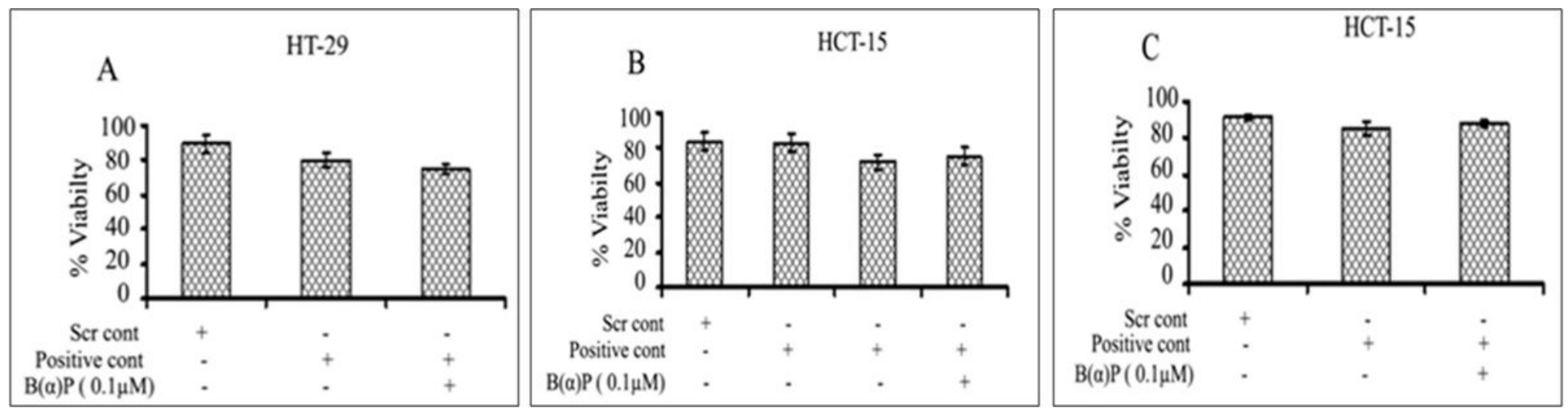

Figure 13

Effect of B(a)P for 48 hours on cell viability (MTT assay) of HCT-15 and HT-29 cells transfected with siRNA of PLA2 (IB, IID and IVA) groups. A. Group IB PLA2 transfected HT-29 cells; B. Group IID PLA2 transfected HCT-15 cells C. Group IVA PLA2 transfected HCT-15 cells. Results are expressed as mean \pm SD of three separate assays. ScrCont: Scrambled control.
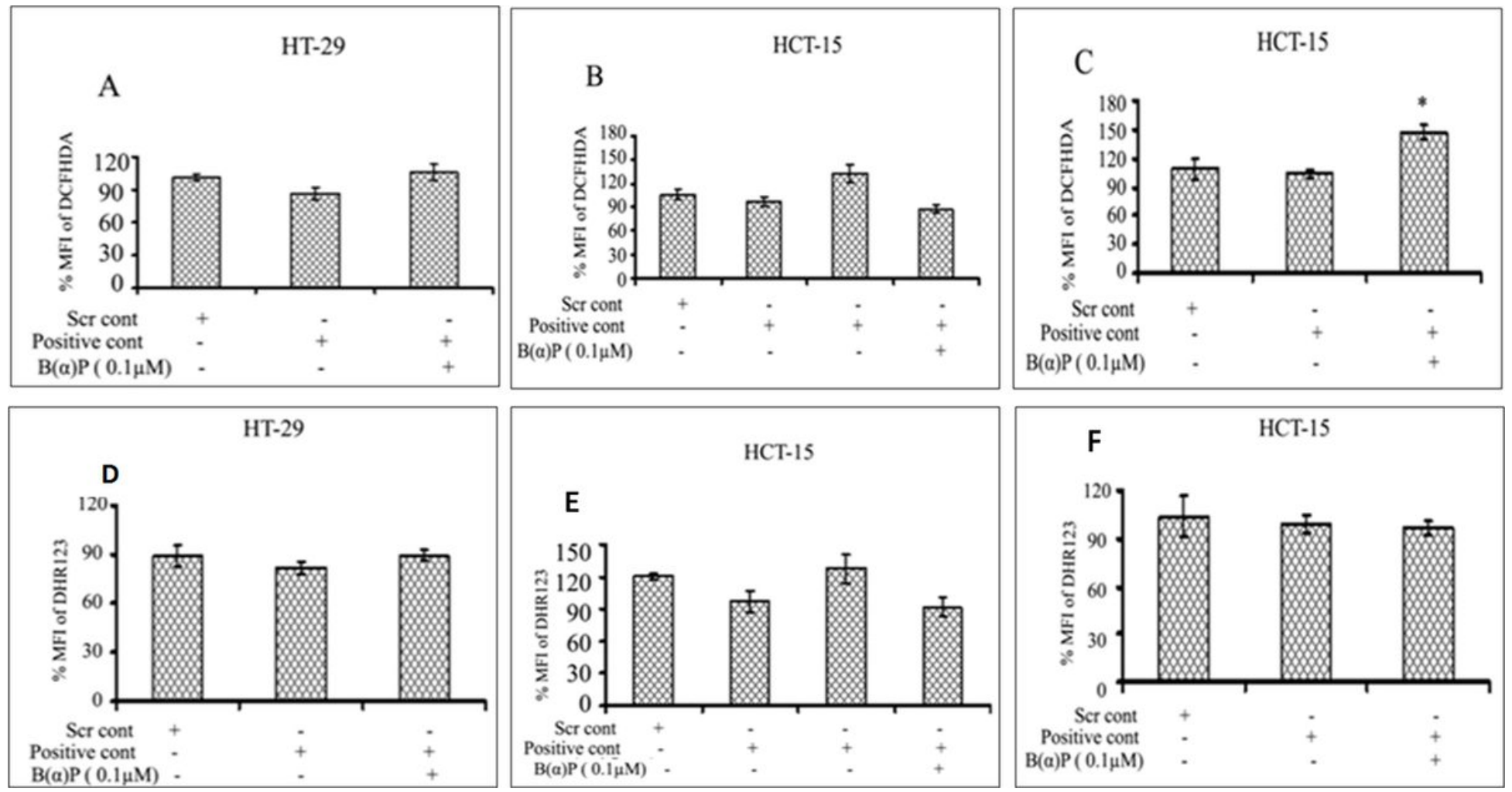

Figure 15

Effect of $\mathrm{B}(\mathrm{a}) \mathrm{P}$ for 48 hours on ROS production (by DCFH-DA fluorescence dye) of HCT-15 and HT-29 cells transfected with siRNA of PLA2 (A) IB (B) IID and (C))IVA groups and on mitochondrial ROS production (by DHR123 fluorescence dye) (D) IB (E) IID and (F)IVA groups. Both the cell lines were treated with concentrations of $0.1 \mu \mathrm{M} \mathrm{B}(\mathrm{a}) \mathrm{P}$ for 48 hours including 30 minutes with fluorescence dye at the end phase. Cells were then washed with sterile PBS, and de-adhered for final analysis. Results are expressed as 
mean $\pm S D$ of three separate assays. ScrCont: Scrambled control. ${ }^{*} p<0.05$; ${ }^{*}$ positive control cells with $\mathrm{B}(\mathrm{a}) \mathrm{P}$ treated cells compared with scrambled control.
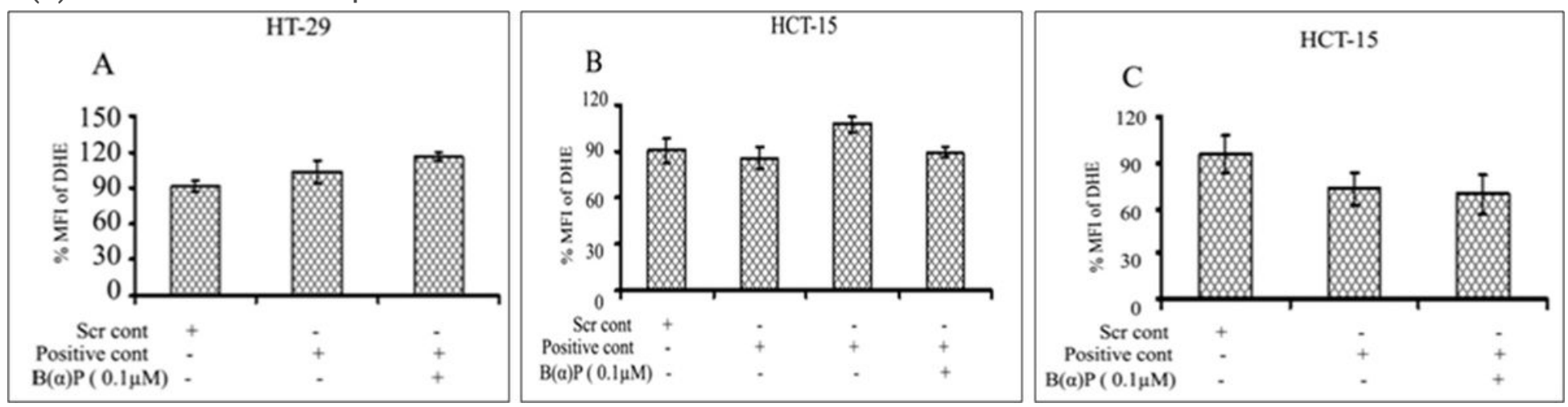

\section{Figure 17}

Effect of $B(a) P$ for 48 hours on SOR production (by DHE fluorescence dye) of HCT-15 and HT-29 cells transfected with siRNA of PLA2 (A) IB, (B)IID and (C) IVA groups. Both the cell lines were treated with concentrations $0.1 \mu \mathrm{M} \mathrm{B}(\mathrm{a}) \mathrm{P}$ for 48 hours including 30 minutes with fluorescence dye at the end phase. Cells were then washed with sterile PBS, and de-adhered for final analysis. Results are expressed as mean $\pm S D$ of three separate assays. ScrCont: Scrambled control.

\section{Supplementary Files}

This is a list of supplementary files associated with this preprint. Click to download.

- Coverletter.doc

- Coverletter.doc 